\title{
Controlling Growth of Sanchezia nobilis Plant by Foliar Application of Micronutrients and Paclobutrazol
}

\author{
Amaal A. M. Heikal \\ Department of Ornamental Horticulture, Faculty of Agriculture, Cairo University, \\ Cairo, Egypt.
}

\begin{abstract}
A POT EXPERIMENT was carried out to evaluate the effect of foliar application of micronutrients mixtures and paclobutrazol on controlling growth of sanchezia plants. The experimental treatments were laid out in a split plot arrangement using a randomized complete block design. Micronutrients mixtures of $\mathrm{Zn}+\mathrm{Mn}+\mathrm{Fe}+\mathrm{B}$ at $50\left(\mathrm{C}_{1}\right), 100\left(\mathrm{C}_{2}\right)$ and $150\left(\mathrm{C}_{3}\right)$ ppm of each element were assigned to main plot, while paclobutrazoltreatments; 8, 16, and 24 $\mathrm{mgL}^{-1}$ were allocate to sup-plot. Spraying plants with tap water represent control treatments.

Foliar application of micronutrients at the level of $\mathrm{C}_{2}$ significantlyenhanced plant growth in terms of plant height, stem diameter, root length, leaf area, number of leaves and inflorescences, fresh and dry matter of leaves, shoots, inflorescences and roots. Total chlorophyll, total carbohydrates, $\mathrm{Fe}, \mathrm{Zn}, \mathrm{Mn}$ and $\mathrm{B}$ contents of leaves increased in plants sprayed with micronutrients.

The most visible effect of paclobutrazol is the decrease in all studied growth traits. Severe retardation of plant growth was evident at $24 \mathrm{mg}$ a.i. $\mathrm{L}^{-1}$ of paclobutrazol. Foliar application of paclobutrazol enhanced total chlorophyll content up to $16 \mathrm{mg} \mathrm{L}^{-1}$. Plant height, stem diameter and root length linearly decrease with the paclobutrazol concentrations. Application of paclobutrazol at the level of $16 \mathrm{mg} \mathrm{L}^{-1}$ markedly increased total carbohydrates and mineral contents of leaves. The significance interaction between micronutrients and paclobutrazol, especially for plant height and leaf area increase the diversity of potted plants grown for the ornamental plants market.
\end{abstract}

Keywords: Sanchezia nobilis, Microelements, Growth Retardants, Vegetative growth, Flowering.

\section{Introduction}

Sanchezia (Sanchezia nobilis) of the family Acanthaceaeis an evergreen semi-woody shrub that grown in tropical and sub-tropical regions for its handsome foliage.It has bright green leaves (up to $30 \mathrm{~cm}$ in length) with prominently marked white veins. The flowers are narrowly tubular, yellow with reddish-orange bracts and are carried on stems in long spikes (Watson and Dallwitz, 1994). Sanchezia has potential as an ornamental pot plant, if the growth can be controlled.

Plant growth regulators (PGRs) either phytohormonesor synthetic compounds are organic compounds, and can be applied in small amounts to promote, inhibit, or otherwise modify any physiological plant process (Tukey et al., 1953). Plant growth retardants, which are synthetic compounds applied to control plant size without obvious phytotoxicity (Davis and Curry, 1991). Plant height control and producing compact or appropriately-sized plants is important for ornamental plants to improve commercial quality and adaptability to shipping and transplanting operations (Agehara and Leskovar, 2014). Under normal growth conditions, sanchezia plant height ranged between $1.3 \mathrm{~m}$ to $2.4 \mathrm{~m}$ and the plant occupies a large area due to its vertical and horizontal spread, which makes it difficult to transport and trade commercially, especially as house-potted plants. Sanchezia with dense foliage can make decorative displays indoors and outdoors. However, for commercial purposes, ornamental sanchezia plants must be compact 
and well branched. Therefore, a technique such as pinching and growth regulators for suppression growth in ornamental plants is a commercial recommendation in ornamental plant production. Pinching is a very labor intensive process; therefore the use of plant growth regulators (PGRs) for height control offers the opportunity of reducing labor costs (Meijon et al., 2009). The majority of PGRs used in ornamental plant culture are inhibitors of gibberellins (GA) biosynthesis and consequently cell elongation (Basra, 2000 and Rademacher, 2000). Triazoles, represented by paclobutrazol and uniconazole, are among the PGRs with this mode of action.

Application of paclobutrazol as growth retardant for different herbaceous and semi-wood plants at the rates varied from 0.5 to $150 \mathrm{mga}$.i. $\mathrm{L}^{-1}$ and for different woody plants at the rates varied from 4 to $10 \mathrm{~g}$ a.i. tree ${ }^{-1}$ has been reported to be effective in controlling vegetative growth, promoting compactness and flower bud initiation of different ornamental crops with varying degrees of success. Application of paclobutrazol to woody plants reduced cambial growth in white oak, red oak, cherrybark oak, sweetgum, European black alder, and white pine (Bai et al., 2004). Application of paclobutrazol to lavender (Papageorgiou et al. (2002), Thymus syrphylum (Bekheta et al., 2003), ornamental pepper,Capsicum annuит (Grossi et al., 2005 andMutlu and Agan, 2015), Zinnia elegans (Pinto et al., 2005), Bougainvillea glabra (Fatma et al., 2007), Consolidaorientalis (Mansuroglu et al. 2009), sea marigold (Carver et al., 2014) suppression plant growth expressed as number of branches, number of leaves, internodes length, plant height, lateral shoot elongation,plant diameter, fresh and dry weight of plant organs, delayed time to anthesis in lavender and, delaying production cycle in Lilliput, but increased leaf chlorophyll content in ornamental pepper and Consolidaorientalis. On the contrary foliar application of paclobutrazol to Scheffleraarboricola plant (Mazher et al., 2014) increasedstem diameter, number of leaves plant ${ }^{-1}$, leaf area, fresh and dry weight for all the plant organs, pigment contents, total carbohydrates and mineral contents $(\mathrm{N}, \mathrm{P}$ and $\mathrm{K})$ in leaves and stems. Matsoukis et al. (2015) reported thatapplication of paclobutrazol to Lantana Camaraplant increased leaf contents of iron and manganese.

For producing appropriately-sized plants, maintaining quality prior to sale, promoting shelf-life, and improving aesthetic quality, proper fertilization is demandedin both macro- and micronutrient after paclobutrazolapplications (Matsoukis et al., 2015). Micronutrients play distinct and vital roles in plant physiological and biochemical processes (Putra et al., 2012). In arid and semi arid regions where soil $\mathrm{pH}$ is always high $(\mathrm{pH}>7.0)$ micronutrients are converted to chemical forms that most ornamental plants cannot absorb. Therefore, most ornamental crops suffer widely by zinc $(\mathrm{Zn})$ deficiency followed by boron (B), Manganese ( $\mathrm{Mn})$ and iron $(\mathrm{Fe})$ which involved in various processes related to photosynthesis and various enzymatic systems (Vasconcelos et al., 2014). Foliar application of $\mathrm{Fe}, \mathrm{Mn}$ and $\mathrm{Zn}$ at 50 or $100 \mathrm{ppm}$ for each element enhanced vegetative growth traits in terms of plant height, leaf area, number of leaves and branches as well as fresh leaves weight of Salvia farinacea (Abd El-Aziz and Balbaa, 2007), CupressussempervirensL (Farahat et al., 2007), Cymbopogoncitratus (Aziz et al., 2010), Gerbera jamesonii (Bashir et al., 2013) and Paulownia kawakamii (El-Quesni et al., 2014). Also foliar application of aforementioned micronutrients increased chlorophyll a, b carotenoids and total soluble sugars contents in leaves of Cupressussempervirens (Farahat et al., 2007) and total chlorophyll, total carbohydrates, $\mathrm{N}, \mathrm{P}, \mathrm{K}$ contents in leaves of Paulownia kawakamii(El- Quesni et al., 2014). Yadegari (2017) reported that foliar application of $\mathrm{Fe}+\mathrm{Mn}$ $+\mathrm{Zn}+\mathrm{Cu}$ at $400 \mathrm{ppm}$ to lemon balm (Melissa officinalis L.) significantly improved fresh and dry shoot matter, fresh and dry root matter, fresh and dry flower matters and number of flower per plant. Despite the use of paclobutrazol in the industry of potted plants, no studies have been published concerning paclobutrazol efficacy for sanchezia plant. The main objective of this work was to understand the influence of paclobutrazol and micro-elements nutrition on growth and chemical constituents of sanchezia plant.

\section{Materials and Methods}

\section{Experimental procedures}

A pot experiment was carried out to study the effect of paclobutrazol and micro-elements fertilizers on growth and chemical constituents of Sanchezia plant in split plot arrangement based on randomized complete block design with three replicates. The experiment was carried out at the Experimental Nursery of the Ornamental Horticulture Department, Faculty of Agriculture, Cairo University, Giza (30 01'39.36”N latitude

Egypt. J. Hort. Vol. 44, No. 2 (2017) 
and $31^{\circ} 12^{\prime} 36.50^{\prime}$ 'E Longitude) during 2015 and 2016 seasons. Soil characteristics in which the pots were filled during the two seasons are presented in Table 1. The homogeneous Sanchezianobilis plants (60 days old and average height of $12 \mathrm{~cm}$ ) produced using tip cuttings in green glass house under mist were selected and transplanted to plastic pots of $30 \mathrm{~cm}$ diameter on the first of May in years 2015 and 2016. The main plot factor was the mixture of iron $(\mathrm{Fe})+$ zinc $(\mathrm{Zn})+$ manganese $(\mathrm{Mn})+$ boron (B) that wasappliedasfoliar applicationsat three differentconcentrations from each, viz.50 ( $\left.\mathrm{C}_{1}\right)$, $100\left(\mathrm{C}_{2}\right)$ and $150\left(\mathrm{C}_{3}\right)$ ppm aswellas, thecontroltr eatmentoftapwater $\left(\mathrm{C}_{0}\right)$. The micro nutrients was applied in the form offerrous sulphateheptahydrate $\left(\mathrm{Fe}_{2} \mathrm{SO}_{4} .7 \mathrm{H}_{2} \mathrm{O}\right)$, zinc sulphateheptahydrate $\left(\mathrm{ZnSO} 4.7 \mathrm{H}_{2} \mathrm{O}\right)$, Manganesesulphateheptahydrate $\left(\mathrm{MnSO}_{4} \cdot 7 \mathrm{H}_{2} \mathrm{O}\right)$ and Boric acid $\left(\mathrm{H}_{3} \mathrm{BO}_{4}\right)$. The micronutrients mixtures were applied three timesat 30,60 and 90 days aftertrans plantinginad ditionto the controltreatment. The sub-plot factor was paclobutrazol in four levels $(0,8,16$ and $24 \mathrm{mg}$ a.i. $\left.\mathrm{L}^{-1}\right)$ that was applied as foliar application. Spraying with tap water represents control treatment (0). A triazole plant growth regulator;bonzi $(0.4 \%$ active ingredient of paclobutrazol) was used. Paclobutrazolwas applied three times; at 25,50 and 75 days after transplanting. Each level of sub plot was represented by six pots for each replicate. Spraying plants with micronutrients or/and paclobutrazol was carried out till the solution just covered the plants and run off. Each pot received $1 \mathrm{~g} \mathrm{~N}$ as soil drenching in the form of ammonium nitrate $(33 \% \mathrm{~N})$ in two equal splits at 30 and 60 days after transplanting. The plants were supplied with regular irrigation water to keep moderate humidity.

\section{Measured characters}

Data of different plant characters were recorded on $30^{\text {th }}$ of November (about 7 months from transplanting) in seasons of 2015 and 2016, respectively.

\section{Growth and flowering traits}

Vegetative growth traits in terms of plant height (cm), stem diameter, number of branches per plant, number of leaves per plant, mean individual leaf area $\left(\mathrm{cm}^{2}\right)$ and fresh leaves weight $(\mathrm{g})$ per plant were determined at each season. Fresh roots weight $(\mathrm{g})$ per plant was determined. Flowering traits in terms of number of inflorescences per plant and inflorescences fresh weight per plant were determined at each season. Fresh weightsfor leaves, roots and inflorescences per plant were dried at $105^{\circ} \mathrm{C}$ for $24 \mathrm{hr}$. and the dry weights $(\mathrm{g})$ were recorded.

TABLE 1. Experimental soil characteristics during 2015 and 2016 seasons.

\begin{tabular}{|c|c|c|}
\hline Soil characteristics & $2014 / 2015$ & $2015 / 2016$ \\
\hline \multicolumn{3}{|l|}{ Physical properties } \\
\hline Sand \% & 65.30 & 68.00 \\
\hline Silt \% & 28.20 & 26.80 \\
\hline Clay \% & 6.50 & 5.20 \\
\hline Soil texture & Sandy loam & Sandy loam \\
\hline \multicolumn{3}{|l|}{ Chemical properties } \\
\hline $\mathrm{pH}$ & 7.80 & 8.10 \\
\hline E.C (ds/m) & 2.33 & 2.25 \\
\hline $\mathrm{Na}(\mathrm{mq} / \mathrm{l})$ & 2.50 & 2.20 \\
\hline $\mathrm{Cl}(\mathrm{mq} / \mathrm{l})$ & 13.80 & 12.00 \\
\hline $\mathrm{CaCO}_{3} \%$ & 14.20 & 15.00 \\
\hline $\mathrm{N}\left(\mathrm{mg} \mathrm{kg}^{-1}\right)$ & 12.63 & 11.00 \\
\hline $\mathrm{P}\left(\mathrm{mg} \mathrm{kg}^{-1}\right)$ & 21.00 & 19.50 \\
\hline $\mathrm{K}\left(\mathrm{mg} \mathrm{kg}^{-1}\right)$ & 95.00 & 84.90 \\
\hline $\mathrm{Fe}\left(\mathrm{mg} \mathrm{kg}^{-1}\right)$ & 6.60 & 5.20 \\
\hline $\mathrm{Zn}\left(\mathrm{mg} \mathrm{kg}^{-1}\right)$ & 0.50 & 0.46 \\
\hline $\mathrm{Mn}\left(\mathrm{mg} \mathrm{kg}^{-1}\right)$ & 3.00 & 2.75 \\
\hline B (mg kg-1) & 0.76 & 0.68 \\
\hline
\end{tabular}




\section{Total chlorophyll}

Total chlorophylls content was determined in the fresh leaves at 120 days after transplanting using chlorophyll meter; model SPAD-502 (Spectrum Technologies Inc., Plainfield, IL), which SPAD unit $=10 \mathrm{mg} / 100 \mathrm{~g}$ fresh weight of leaves (Netto et al., 2005).

\section{Total carbohydrates}

Total carbohydrates content was determined according to Dubois et al. (1956) in homogenized samples $(0.2 \mathrm{~g})$ of leaves dried at $70^{\circ} \mathrm{C}$ for 48 hours

\section{Elements determination}

Fresh leaves samples were dried in oven at $70^{\circ} \mathrm{C}$ for 48 hours. The dried samples were then digested for extraction of nutrients, using the method described by Piper (1947). Concentrated sulphuric acid $(5 \mathrm{ml})$ was added to $0.5 \mathrm{~g}$ dried samples and the mixture was heated for $10 \mathrm{~min}$ and then $0.5 \mathrm{ml}$ of perchloric acid was added and heating continued till a clear solution was obtained. The digested solution was quantitatively transferred to a $100 \mathrm{ml}$ volumetric flask using deionized water. Iron, zinc, manganese and boron were determined using a "PyeUnicam, Model SP 1900 " atomic absorption spectrophotometer with a boiling air-acetylene burner and recorded read out (Issac and Kerber, 1971).

\section{Statistical analysis}

Data recorded on vegetative growth traits and total chlorophylls were analyzed using analysis of variance based on a split-plot arrangement in a randomized complete block design according to procedures outlined by Gomez and Gomez (1984) using MSTAT-C computer package (Freed et al., 1989). Treatment mean comparisons were performed using least significant difference (LSD) at $5 \%$ level of probability. Data on growth traits, flowering traits and total chlorophyll content were averaged over seasons and subjected to polynomial regression analysis to establish the concentration response curves of growth retardants.

\section{Results and Discussion}

Data presented in Table 2 revealed that plant height, stem diameter, branches number per plant and root length of sanchezia plants positively responded to foliar application of micronutrients mixtures in the two growing seasons. Spraying plants with micronutrients mixtures at the level of $\mathrm{C}_{2}(100 \mathrm{Zn}+100 \mathrm{Mn}+100 \mathrm{Fe}+100 \mathrm{~B}$; in $\mathrm{ppm})$ significantly gave the highest values of plant height (38.32 and $34.44 \mathrm{~cm}$ ), stem diameter
(6.20 and $5.71 \mathrm{~mm})$, branches number $(7.50$ and $6.79)$ and root length $(54.79$ and $46.13 \mathrm{~cm})$ in the first and second seasons, respectively. The plants treated with micronutrientsshows increasedin plant height, stem diameter, branches number and root length due to the role of $\mathrm{Zn}$ in synthesis oftryptophan, which is a precursor of auxin (IAA) and isessential in nitrogen metabolism, which stimulates growth. The aforesaid results were in accordance with Abd El-Aziz and Balbaa (2007), Aziz et al. (2010), Bashir et al. (2013) and ElQuesni et al. (2014).

Foliar application of paclobutrazol at 8, 16 and $24 \mathrm{mg}$ a.i. $\mathrm{L}^{-1}$ significantly reduced all aforementioned traits compared to nontreated plants (Table 2). The rate of reduction increased with increasing the concentration of paclobutrazol. Therefore, the effective rate in reduction of plant growth was $24 \mathrm{mg}$ a.i. $\mathrm{L}^{-1}$ of paclobutrazol. Severe retardation of plant height, stem diameter, branches number and root length was evident at $24 \mathrm{mg}$ a.i. $\mathrm{L}^{-1}$ of paclobutrazol in both seasons. Sancheziaplants which sprayed with 8,16 and 24 $\mathrm{mg}$ a.i. $\mathrm{L}^{-1}$ paclobutrazol were $26.28 \%, 44.54 \%$ and $57.47 \%$ shorter than untreated plants, respectively in the first season, corresponding to $24.02 \%, 37.98 \%$ and $55.10 \%$ in the second season. Plant height, stem diameter and root length linearly decrease with the paclobutrazol concentrations, while number of branches was best explained by a third-order polynomial (Figs. 1, 2, 3 and 4). Paclobutrazol decreases the height of plant by preventing gibberellins biosynthesis and consequently decreasing the cell division in meristematic regions of stem. Gibberellins cause an increase in cell division and acceleration of stem growth (Basra, 2000 and Rademacher, 2000). The adversely effect of paclobutrazol on plant height, stem diameter and number of branches of different ornamental plants was reported by Papageorgiou et al. (2002), Grossi et al. (2005), Fatma et al. (2007), Mansuroglu et al. (2009), Carver et al. (2014) andMutlu and Agan (2015). The interaction between micronutrients and paclobutrazol was significant for plant height and root length in both seasons. The highest values of plant height and root length were measured in nontreated plants with paclobutrazol, but sprayed with micronutrients mixture at the level of $\mathrm{C}_{2}$, while the lowest values of plant height and root length was measured in nontreated plants with micronutrients, but sprayed with paclobutrazol at the level of $24 \mathrm{mg}$ a.i. $\mathrm{L}^{-1}$ in both seasons. 
TABLE 2. Effect of foliar application of micronutrients mixture and paclobutrazol (PB) on growth traits of Sanchezianobilis plant during 2015 and 2016 seasons.

\begin{tabular}{|c|c|c|c|c|c|c|c|c|c|}
\hline \multirow{2}{*}{$\begin{array}{l}\text { Micronutrients } \\
\text { mixture (ppm) }\end{array}$} & \multirow{2}{*}{$\begin{array}{c}\text { PB } \\
(\mathrm{mg} \text { a.i.L. } \\
\left.-L^{-1}\right)\end{array}$} & \multicolumn{2}{|c|}{$\begin{array}{c}\text { Plant height } \\
(\mathrm{cm})\end{array}$} & \multicolumn{2}{|c|}{$\begin{array}{l}\text { Stem diameter } \\
(\mathrm{mm})\end{array}$} & \multicolumn{2}{|c|}{$\begin{array}{l}\text { Branches } \\
\text { No/plant }\end{array}$} & \multicolumn{2}{|c|}{$\begin{array}{l}\text { Root length } \\
\text { (cm) }\end{array}$} \\
\hline & & 2015 & 2016 & 2015 & 2016 & 2015 & 2016 & 2015 & 2016 \\
\hline \multirow{4}{*}{$\mathrm{C}_{0}$} & 0 & 48.00 & 41.33 & 6.00 & 5.67 & 9.00 & 8.17 & 60.00 & 55.00 \\
\hline & 8 & 35.33 & 31.50 & 5.67 & 5.17 & 6.33 & 5.50 & 48.33 & 41.67 \\
\hline & 16 & 26.67 & 25.33 & 4.83 & 4.52 & 5.17 & 5.00 & 39.00 & 33.67 \\
\hline & 24 & 19.00 & 17.67 & 4.17 & 3.83 & 4.00 & 4.00 & 31.67 & 28.67 \\
\hline Mean & & 32.25 & 28.96 & 5.17 & 4.80 & 6.13 & 5.67 & 44.75 & 39.75 \\
\hline \multirow{4}{*}{$C_{1}$} & $\mathbf{0}$ & 52.67 & 44.67 & 6.83 & 6.00 & 9.33 & 8.33 & 65.00 & 58.17 \\
\hline & 8 & 39.00 & 33.82 & 6.00 & 5.67 & 7.00 & 5.67 & 55.00 & 45.33 \\
\hline & 16 & 29.67 & 27.33 & 5.17 & 5.00 & 6.33 & 5.17 & 45.00 & 37.67 \\
\hline & 24 & 22.00 & 20.00 & 4.67 & 4.17 & 5.33 & 4.33 & 36.00 & 33.67 \\
\hline Mean & & 35.84 & 31.46 & 5.67 & 5.21 & 7.00 & 5.87 & 50.25 & 43.71 \\
\hline \multirow{4}{*}{$\mathrm{C}_{2}$} & $\mathbf{0}$ & 56.27 & 48.00 & 7.80 & 6.50 & 9.67 & 9.00 & 70.17 & 60.00 \\
\hline & 8 & 41.00 & 36.67 & 6.33 & 6.17 & 7.67 & 6.50 & 58.33 & 47.00 \\
\hline & 16 & 31.00 & 30.83 & 5.67 & 5.50 & 6.67 & 6.00 & 50.67 & 40.33 \\
\hline & 24 & 25.00 & 22.27 & 5.00 & 4.67 & 6.00 & 5.67 & 40.00 & 37.17 \\
\hline Mean & & 38.32 & 34.44 & 6.20 & 5.71 & 7.50 & 6.79 & 54.79 & 46.13 \\
\hline \multirow{4}{*}{$\mathrm{C}_{3}$} & $\mathbf{0}$ & 54.67 & 46.33 & 7.55 & 6.00 & 9.27 & 8.33 & 68.00 & 59.00 \\
\hline & 8 & 40.67 & 35.00 & 5.67 & 6.00 & 7.00 & 6.00 & 54.00 & 45.33 \\
\hline & 16 & 30.00 & 28.33 & 5.27 & 5.00 & 6.15 & 5.67 & 47.33 & 38.33 \\
\hline & 24 & 24.00 & 21.00 & 4.50 & 4.27 & 6.00 & 5.50 & 37.33 & 36.33 \\
\hline Mean & & 37.34 & 32.67 & 5.75 & 5.32 & 7.11 & 6.37 & 51.67 & 44.75 \\
\hline \multirow{4}{*}{$\begin{array}{l}\text { Mean of } \\
\text { paclobutrazol }\end{array}$} & 0 & 52.90 & 45.08 & 7.05 & 6.04 & 9.32 & 8.46 & 65.79 & 58.04 \\
\hline & 8 & 39.00 & 34.25 & 5.92 & 5.75 & 7.00 & 5.92 & 53.92 & 44.83 \\
\hline & 16 & 29.34 & 27.96 & 5.23 & 5.01 & 6.08 & 5.46 & 45.50 & 37.50 \\
\hline & 24 & 22.50 & 20.24 & 4.58 & 4.23 & 5.33 & 4.88 & 36.25 & 33.96 \\
\hline \multicolumn{10}{|l|}{ LSD at $5 \%$} \\
\hline Micro-nutrients (M) & & 2.35 & 1.87 & 0.72 & 0.65 & 0.74 & 0.60 & 3.69 & 2.23 \\
\hline Paclobutrazol (PB) & & 1.79 & 1.84 & 0.61 & 0.41 & 0.62 & 0.52 & 2.97 & 1.47 \\
\hline M X PB & & 3.58 & 3.49 & $\mathrm{n} . \mathrm{s}$ & n.s & n.s & n.s & 4.32 & 3.22 \\
\hline
\end{tabular}

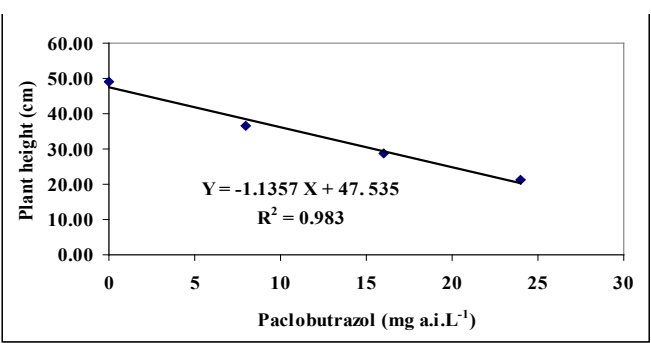

Fig 1. Plant height of Sanchezia nobilis plant as affected by foliar spray of paclobutrazol (mg a.i. $\left.\mathbf{L}^{-1}\right)$.

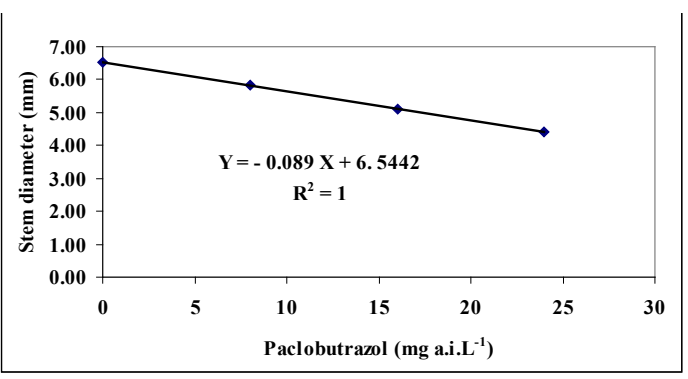

Fig. 2. Stem diameter of Sanchezia nobilis plant as affected by foliar spray of paclobutrazol ( $\mathrm{mg}$ a.i. $\mathbf{L}^{-1)}$ 


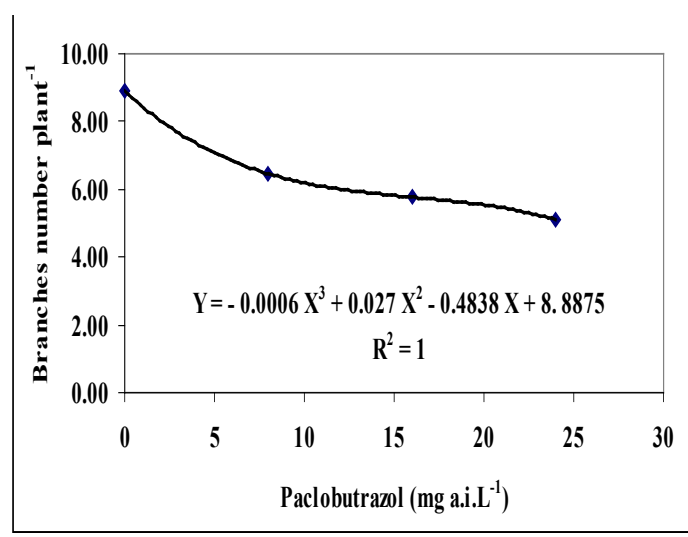

Fig. 3. Branches number of Sanchezia nobilis plant as affected by foliar spray of paclobutrazol (mg a.i. $\left.\mathbf{L}^{-1}\right)$.

Data presented in Table 3 showed that application of micronutrients mixtures enhanced plant growth in terms of individual leaf area, number of leaves per plant, fresh and dry leaves weights per plantin contrast to control treatment $\left(\mathrm{C}_{0}\right)$ in the two growing seasons. Foliar application of micronutrients mixtures at the level of $\mathrm{C}_{2}$ $(100 \mathrm{Zn}+100 \mathrm{Mn}+100 \mathrm{Fe}+100 \mathrm{~B}$; in ppm) significantly gave the highest values of leaf area (94.88 and $81.74 \mathrm{~cm}^{2}$ ), number of leaves per plant (46.17and 42.58), fresh weight of leaves (197.59 and $165.62 \mathrm{~g}$ ) and dry weight of leaves (45.20 and $38.17 \mathrm{~g}$ ) in the first and second seasons, respectively. Increased in leaf area and numberof leaves per plant may be due to the enhancement role of micronutrients in cell division in plants. The enhancement effect of application of micronutrients on leaf area, number of leaves per plant and leaves weightof differentornamental plants was reported by Abd El-Aziz and Balbaa (2007),Farahat et al. (2007), Aziz et al. (2010), Bashir et al. (2013) and El-Quesni et al. (2014).

Foliar application of the growth retardant; paclobutrazol to sanchezia plants significantly reduced individual leaf area, number of leaves per plant, fresh and dry leaves weights per plant compared to nontreated plants in both seasons (Table 3). The rate of reduction increased with increasing the concentration of paclobutrazol. Severe retardation of aforementioned traits was evident at $24 \mathrm{mg}$ a.i. $\mathrm{L}^{-1}$ of paclobutrazol in both seasons. Application of paclobutrazol at the rate of 8,16 and $24 \mathrm{mg}$ a.i. $\mathrm{L}^{-1}$ reduced leaf area $(44.99 \%, 53.36 \%$ and $58.03 \%)$, leaves number

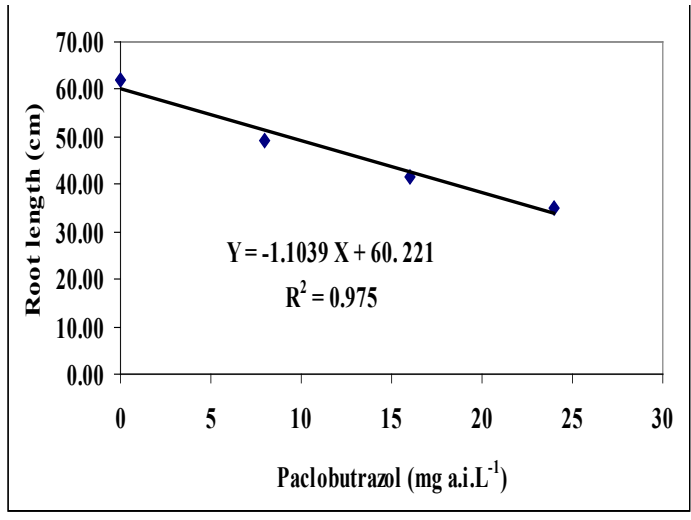

Fig. 4. Root length of Sanchezia nobilis plant as affected by foliar spray of paclobutrazol (mg a.i. $\left.\mathbf{L}^{-1}\right)$.

$(22.22 \%, 35.49 \%, 42.31 \%)$ and fresh weight of leaves $(35.79 \%, 48.80 \%, 54.27 \%)$ compared to untreated plants, respectively in the first season, corresponding to $(51.06 \%, 56.52 \%$ and $59.53 \%$ ), $(20.88 \%, 31.45 \%$ and $38.47 \%)$ and $(36.63 \%$, $47.79 \%$ and $52.76 \%$ ) for leaf area, leaves number and fresh leaves weight, respectively in the second season. Leaf area was best explained by a third-order polynomial with the paclobutrazol concentrations, while leaves number and fresh leaves weight were best explained by a secondorder polynomial (Figs. 5, 6 and 7). Reduction in all studied growth traits of sanchezia plants was the most visible effect of foliar application of paclobutrazol. The plants treated with this substance, become short and condensed; this might be due to the decrease in the surface area of leaves and the decrease in the stem growth. The suppression effect of paclobutrazol on leaf area, number of leaves and weight of leaves per planthas been reported by Papageorgiou et al. (2002), Grossi et al. (2005), Fatma et al. (2007), Mansuroglu et al. (2009), Carver et al. (2014) andMutlu and Agan (2015) on differentornamental plants. The interaction between micronutrients and paclobutrazol was significant for individual leaf area, fresh and dry weight of leaves in both seasons. The highest values of those traitswere measured in plants sprayed with micronutrients mixture at the level of $\mathrm{C}_{2}$, but nontreated with paclobutrazol, while the lowest values were measured in plants sprayed with paclobutrazol at the level of $24 \mathrm{mg}$ a.i. $\mathrm{L}^{-1}$, but nontreated with micronutrientsin both seasons. 
TABLE 3. Effect of foliar application of micronutrients mixture and paclobutrazol (PB) on growth traits of Sanchezia nobilis plant during 2015 and 2016 seasons.

\begin{tabular}{|c|c|c|c|c|c|c|c|c|c|}
\hline \multirow{3}{*}{$\begin{array}{l}\text { Micronutrients } \\
\text { mixture (ppm) }\end{array}$} & \multirow{3}{*}{$\begin{array}{c}\text { PB } \\
\left(\mathrm{mg} \text { a.i. } \mathrm{L}^{-1}\right)\end{array}$} & \multirow{2}{*}{\multicolumn{2}{|c|}{ Leaf area $\left(\mathrm{cm}^{2}\right)$}} & \multicolumn{6}{|c|}{ Leaves per plant } \\
\hline & & & & \multicolumn{2}{|c|}{ Number } & \multicolumn{2}{|c|}{ Fresh weight (g) } & \multicolumn{2}{|c|}{ Dry weight (g) } \\
\hline & & 2015 & 2016 & 2015 & 2016 & 2015 & 2016 & 2015 & 2016 \\
\hline \multirow{4}{*}{$\mathrm{C}_{0}$} & $\mathbf{0}$ & 139.99 & 128.33 & 54.00 & 49.27 & 246.11 & 225.67 & 58.29 & 54.75 \\
\hline & 8 & 78.84 & 61.33 & 43.67 & 38.00 & 152.30 & 140.39 & 35.36 & 32.93 \\
\hline & 16 & 67.90 & 54.29 & 36.27 & 34.27 & 122.26 & 115.22 & 29.38 & 28.14 \\
\hline & 24 & 59.42 & 45.67 & 32.67 & 30.33 & 105.52 & 102.94 & 25.65 & 24.99 \\
\hline \multicolumn{2}{|l|}{ Mean } & 86.54 & 72.41 & 41.65 & 37.97 & 156.55 & 146.06 & 37.17 & 35.20 \\
\hline \multirow{4}{*}{$\mathrm{C}_{1}$} & $\mathbf{0}$ & 150.30 & 133.13 & 55.33 & 51.67 & 282.83 & 239.62 & 61.66 & 55.26 \\
\hline & 8 & 81.41 & 66.84 & 45.00 & 40.00 & 169.31 & 150.27 & 41.10 & 36.33 \\
\hline & 16 & 69.63 & 59.04 & 37.67 & 35.00 & 137.30 & 123.56 & 32.49 & 30.03 \\
\hline & 24 & 61.02 & 52.81 & 34.33 & 31.67 & 126.97 & 109.90 & 29.99 & 26.42 \\
\hline \multicolumn{2}{|l|}{ Mean } & 90.59 & 77.95 & 43.08 & 39.59 & 179.10 & 155.84 & 41.31 & 37.01 \\
\hline \multirow{4}{*}{$\mathbf{C}_{2}$} & 0 & 155.20 & 138.79 & 63.67 & 54.33 & 292.19 & 247.27 & 66.60 & 58.96 \\
\hline & 8 & 86.45 & 67.74 & 47.00 & 44.33 & 199.17 & 161.28 & 46.26 & 37.33 \\
\hline & 16 & 71.22 & 60.85 & 39.00 & 37.67 & 157.48 & 132.26 & 36.77 & 30.40 \\
\hline & 24 & 66.65 & 59.58 & 35.00 & 34.00 & 141.53 & 121.66 & 31.17 & 26.00 \\
\hline \multicolumn{2}{|l|}{ Mean } & 94.88 & 81.74 & 46.17 & 42.58 & 197.59 & 165.62 & 45.20 & 38.17 \\
\hline \multirow{4}{*}{$\mathrm{C}_{3}$} & $\mathbf{0}$ & 152.95 & 134.41 & 61.00 & 53.27 & 289.30 & 244.06 & 63.79 & 57.80 \\
\hline & 8 & 82.50 & 65.72 & 46.33 & 42.67 & 192.25 & 154.26 & 41.31 & 35.52 \\
\hline & 16 & 70.35 & 58.30 & 38.00 & 36.00 & 151.46 & 128.37 & 33.98 & 29.04 \\
\hline & 24 & 64.05 & 58.30 & 33.00 & 32.33 & 133.76 & 117.43 & 29.76 & 28.39 \\
\hline \multicolumn{2}{|l|}{ Mean } & 92.46 & 79.18 & 44.58 & 41.07 & 191.69 & 161.03 & 42.21 & 37.69 \\
\hline \multirow{4}{*}{$\begin{array}{l}\text { Mean of } \\
\text { paclobutrazol }\end{array}$} & 0 & 149.61 & 133.66 & 58.50 & 52.14 & 277.61 & 239.16 & 62.59 & 56.69 \\
\hline & 8 & 82.30 & 65.41 & 45.50 & 41.25 & 178.26 & 151.55 & 41.01 & 35.53 \\
\hline & 16 & 69.77 & 58.12 & 37.74 & 35.74 & 142.13 & 124.85 & 33.16 & 29.40 \\
\hline & 24 & 62.79 & 54.09 & 33.75 & 32.08 & 126.95 & 112.98 & 29.14 & 26.45 \\
\hline \multicolumn{10}{|l|}{ LSD at $5 \%$} \\
\hline \multicolumn{2}{|c|}{ Micro-nutrients (M) } & 3.60 & 3.67 & 2.13 & 2.33 & 5.28 & 5.32 & 2.42 & 1.78 \\
\hline \multicolumn{2}{|c|}{ Paclobutrazol (PB) } & 3.37 & 3.18 & 3.01 & 3.62 & 3.80 & 4.79 & 2.03 & 1.59 \\
\hline \multicolumn{2}{|l|}{ M X PB } & 4.74 & 4.37 & n.s & n.s & 7.61 & 7.59 & 3.05 & 2.19 \\
\hline
\end{tabular}

$\mathrm{PB}=$ Paclobutrazol, a.i. $=$ active ingredient

$\mathrm{C}_{0}=$ control treatment (tap water), $\mathrm{C}_{1}=50 \mathrm{Zn}+50 \mathrm{Mn}+50 \mathrm{Fe}+50 \mathrm{~B}$ in ppm,

$\mathrm{C}_{2}=100 \mathrm{Zn}+100 \mathrm{Mn}+100 \mathrm{Fe}+100 \mathrm{~B}$ in ppm, $\mathrm{C}_{3}=150 \mathrm{Zn}+150 \mathrm{Mn}+150 \mathrm{Fe}+150 \mathrm{~B}$ in ppm

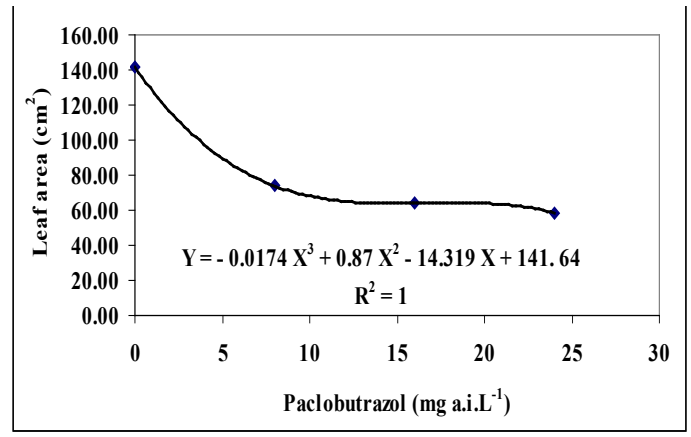

Fig. 5. Leaf area of Sanchezia nobilis plant as affected by foliar spray of paclobutrazol $\left(\mathrm{mg}\right.$ a.i. $\left.\mathrm{L}^{-1}\right)$.

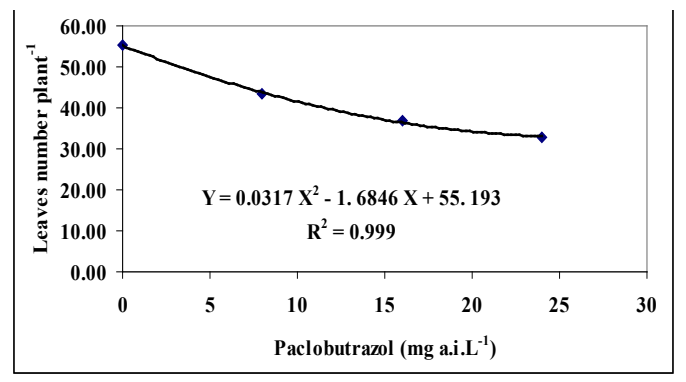

Fig. 6. Leaves number of Sanchezia nobilis plant as affected by foliar spray of paclobutrazol (mg a.i. $\left.L^{-1}\right)$.

Egypt. J. Hort. Vol. 44, No. 2 (2017) 


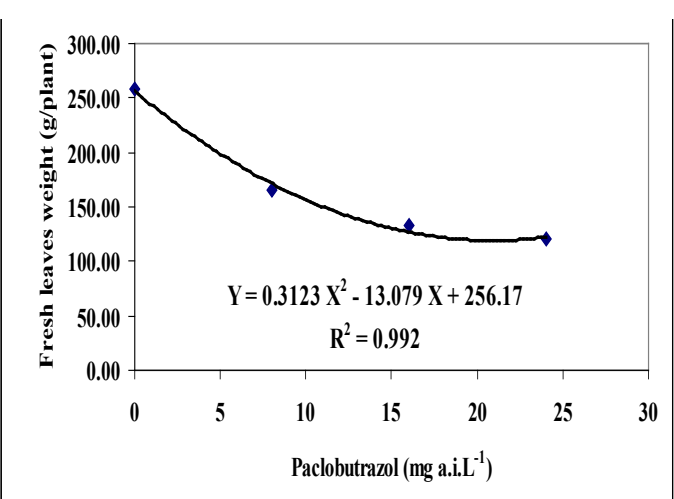

Fig. 7. Fresh leaves weight of Sanchezia nobilis plant as affected by foliar spray of paclobutrazol (mg a.i. $\mathrm{L}^{-1}$ ).

Data in Table 4 cleared that foliar application of micronutrients mixtures had a significant effect on shoot and root weights per plant either in fresh or in dry weights in both seasons. The Maximum value for fresh shoot weight (311.77 and 261.23 $\mathrm{g})$, dry shoot weight (81.51 and $68.11 \mathrm{~g}$ ), fresh root weight (44.24 and $37.47 \mathrm{~g}$ ) and dry root weight (13.59 and $11.45 \mathrm{~g}$ ) resulted from spraying plants with micronutrients mixture at the level of $\mathrm{C}_{2}(100 \mathrm{Zn}+100 \mathrm{Mn}+100 \mathrm{Fe}+100 \mathrm{~B}$; in $\mathrm{ppm})$ in the first and second seasons, respectively. Increase in shoot weight with foliar application of micronutrients could be explained by increase in plant height, stem diameter and number of branches. Enhancement of fresh and dry shoot matter as well as fresh and dry root matter has been also reported by Yadegari (2017).

All paclobutrazol treated plants exhibited significant lower fresh and dry weights of shoots and roots per plant than untreated plants in both seasons (Table 4). Foliar application of paclobutrazol at $24 \mathrm{mg}$ a.i. $\mathrm{L}^{-1}$ was the most effective treatment, since the reduction in weights of shoots and roots of sanchezia plants either in fresh or dry weights was more than $50 \%$ in both seasons. Decrease in shoot weight with foliar application of paclobutrazol could be explained by decrease in plant height, stem diameter and number of branches.Fresh weights of shoots and roots were best explained by a second-order polynomial with the paclobutrazol concentrations (Figs. 8 and 9). The interaction between micronutrients and paclobutrazol was significant for fresh and dry weights of shoots and roots per plant in both seasons. The highest values of those traits were measured in plants sprayed with micronutrients mixture at the level of $\mathrm{C}_{2}$, but nontreated with paclobutrazol, while the lowest values were measured in plants sprayed with paclobutrazol at the level of $24 \mathrm{mg}$ a.i. $\mathrm{L}^{-1}$, but nontreated with micronutrients in both seasons.

Foliar application of micronutrients mixtures significantly increased number of inflorescences per plant, fresh and dry weight of inflorescences per plant and SPAD total chlorophyll of sanchezia plants compared to nontreated plants in the two growing seasons (Table 5). Spraying plants with micronutrients at the level of $\mathrm{C}_{2}(100 \mathrm{Zn}+100$ $\mathrm{Mn}+100 \mathrm{Fe}+100 \mathrm{~B}$; in ppm) gave the highest values of inflorescences numbers (1.92 and 1.85), inflorescences fresh weight (33.23 and $30.34 \mathrm{~g}$ ) and inflorescences dry weight (6.94 and $6.30 \mathrm{~g}$ ), while Spraying plants with micronutrients at the level of $\mathrm{C}_{3}(150 \mathrm{Zn}+150 \mathrm{Mn}+150 \mathrm{Fe}+150 \mathrm{~B}$; in ppm $)$ gave the highest values of leaves total chlorophyll (62.00 and 59.85 SPAD) in the first and second seasons respectively. Similar results were reported by Farahat et al. (2007) and El- Quesni et al. (2014).

Foliar application of paclobutrazol at the level of $8 \mathrm{mg}$ a.i.L-1 ${ }^{-1}$ significantly improved flowering characteristics of sanchezia plants in terms ofinflorescences numbers per plant and inflorescences fresh and dry weights per plant compared to non treated plants, while its application at the level of $16 \mathrm{mg}$ a.i. $\mathrm{L}^{-1}$ had no significant effect on flowering characteristicsduring the two seasons (Table 5). Foliar application of paclobutrazol at the level of $24 \mathrm{mg}$ a.i. $\mathrm{L}^{-1}$ prevented flowering of sanchezia plantsand this may be due to the lack of sufficient vegetative growth to encourage plants to bloom. Number and fresh weight of inflorescences were best explained by a second-order polynomial with the paclobutrazol concentrations (Figs. 10 and 11). Foliar application of paclobutrazol enhanced total chlorophyll content up to $16 \mathrm{mg}$ a.i. $\mathrm{L}^{-1}$, thereafter high concentrations of paclobutrazol reduced total chlorophyll contents in leaves. However, all paclobutrazol treated plants exhibited greener leaves than untreated plants. Response of total chlorophyll content to paclobutrazol was best explained by a second-order polynomial (Fig. 12). However, it is not clear whether increased chlorophyll content is due to enhanced chlorophyll biosynthesis or attributed to more densely packed chloroplasts per unit leaf area as a resultof reduced leaf expansion (Davis et al., 1988 and Khalil, 1995). Also Fletcher et al. (2000) reported that the increase in chlorophyll content in leaves was attributed to the role of Triazoles in stimulating 
cytokinin synthesis that enhances chloroplast differentiation, chlorophyll biosynthesis, and prevents chlorophyll degradation. The findings discussed above are in conformity with reports made by Grossi et al. (2005), Mansuroglu et al. 2009), Mazher et al. (2014) and Mutlu and Agan (2015). The interaction between micronutrients and paclobutrazol was significant for aforementioned traits in both seasons. The highest values of flowering characteristics were measured in plants sprayed with micronutrients mixture at the levels of $\mathrm{C}_{2}$ or $\mathrm{C}_{3}$ and paclobutrazol at the level of $8 \mathrm{mg}$ a.i. $\mathrm{L}^{-1}$. Application of micronutrients mixtureswith paclobutrazol at the levels of 8 or/ and $16 \mathrm{mg}$ a.i. $\mathrm{L}^{-1}$ exhibited high contents of total chlorophyll during the two seasons.

Data in Table (6) revealed that foliar application

TABLE 4. Effect of foliar application of micronutrients mixture and paclobutrazol (PB) on growth traits of Sanchezia nobilis plant during 2015 and 2016 seasons.

\begin{tabular}{|c|c|c|c|c|c|c|c|c|c|}
\hline \multirow{2}{*}{$\begin{array}{l}\text { Micronutrients } \\
\text { mixture (ppm) }\end{array}$} & \multirow{2}{*}{$\begin{array}{c}\text { PB } \\
\left(\mathrm{mg} \text { a.i. } \mathrm{L}^{-1}\right)\end{array}$} & \multicolumn{2}{|c|}{$\begin{array}{c}\text { Shoot fresh weight/ } \\
\text { plant (g) }\end{array}$} & \multicolumn{2}{|c|}{$\begin{array}{c}\text { Shoot dry } \\
\text { weight/plant (g) }\end{array}$} & \multicolumn{2}{|c|}{$\begin{array}{c}\text { Root fresh } \\
\text { weight/plant (g) }\end{array}$} & \multicolumn{2}{|c|}{$\begin{array}{c}\text { Root dry weight/ } \\
\text { plant (g) }\end{array}$} \\
\hline & & 2015 & 2016 & 2015 & 2016 & 2015 & 2016 & 2015 & 2016 \\
\hline \multirow{3}{*}{$\mathrm{C}_{0}$} & $\mathbf{0}$ & 387.58 & 346.17 & 100.15 & 91.49 & 55.30 & 45.50 & 16.95 & 14.09 \\
\hline & 8 & 236.59 & 211.86 & 60.14 & 54.32 & 40.58 & 33.80 & 12.45 & 10.46 \\
\hline & 24 & 170.44 & 162.51 & 45.86 & 44.18 & 21.84 & 20.62 & 7.06 & 6.60 \\
\hline Mean & & 247.21 & 223.93 & 64.32 & 59.15 & 36.90 & 32.41 & 11.33 & 10.04 \\
\hline \multirow{2}{*}{$\mathrm{C}_{1}$} & $\mathbf{0}$ & 425.82 & 369.66 & 111.91 & 96.83 & 61.97 & 46.74 & 19.00 & 14.18 \\
\hline & 8 & 262.83 & 225.19 & 69.90 & 58.44 & 44.07 & 36.35 & 13.53 & 11.26 \\
\hline Mean & & 280.29 & 239.04 & 73.13 & 62.14 & 41.63 & 34.46 & 12.79 & 10.54 \\
\hline \multirow{4}{*}{$\mathrm{C}_{2}$} & $\mathbf{0}$ & 442.32 & 393.30 & 117.56 & 101.06 & 66.27 & 47.97 & 20.35 & 14.39 \\
\hline & 8 & 315.33 & 248.56 & 82.78 & 66.51 & 45.68 & 39.71 & 13.99 & 12.30 \\
\hline & 16 & 254.05 & 203.79 & 67.95 & 54.25 & 37.65 & 35.43 & 11.16 & 10.64 \\
\hline & 24 & 235.37 & 199.27 & 57.76 & 50.61 & 27.38 & 26.75 & 8.85 & 8.48 \\
\hline Mean & & 311.77 & 261.23 & 81.51 & 68.11 & 44.24 & 37.47 & 13.59 & 11.45 \\
\hline $\mathrm{C}_{3}$ & $\mathbf{0}$ & 435.01 & 389.77 & 111.44 & 99.20 & 63.65 & 46.78 & 17.75 & 14.03 \\
\hline \multirow{3}{*}{$\begin{array}{l}\text { Mean of } \\
\text { paclobutrazol }\end{array}$} & 8 & 274.75 & 231.83 & 72.22 & 60.48 & 43.38 & 36.81 & 13.80 & 11.52 \\
\hline & 16 & 226.33 & 191.10 & 59.41 & 50.26 & 34.21 & 32.47 & 10.14 & 9.67 \\
\hline & 24 & 202.77 & 180.04 & 52.64 & 46.83 & 25.28 & 24.03 & 8.17 & 7.52 \\
\hline \multicolumn{10}{|l|}{ LSD at $5 \%$} \\
\hline Micro-nutrients (M) & & 9.79 & 10.50 & 2.54 & 3.01 & 1.60 & 1.88 & 0.51 & 0.44 \\
\hline Paclobutrazol (PB) & & 8.05 & 11.12 & 3.59 & 3.35 & 2.07 & 1.63 & 0.71 & 0.58 \\
\hline M X PB & & 12.09 & 15.25 & 4.17 & 5.69 & 4.15 & 3.26 & 1.42 & 0.96 \\
\hline
\end{tabular}

$\mathrm{PB}=$ Paclobutrazol, a.i. $=$ active ingredient

$\mathrm{C}_{0}=$ control treatment (tap water), $\mathrm{C}_{1}=50 \mathrm{Zn}+50 \mathrm{Mn}+50 \mathrm{Fe}+50 \mathrm{~B}$ in ppm,

$\mathrm{C}_{2}=100 \mathrm{Zn}+100 \mathrm{Mn}+100 \mathrm{Fe}+100 \mathrm{~B}$ in ppm, $\mathrm{C}_{3}=150 \mathrm{Zn}+150 \mathrm{Mn}+150 \mathrm{Fe}+150 \mathrm{~B}$ in ppm 


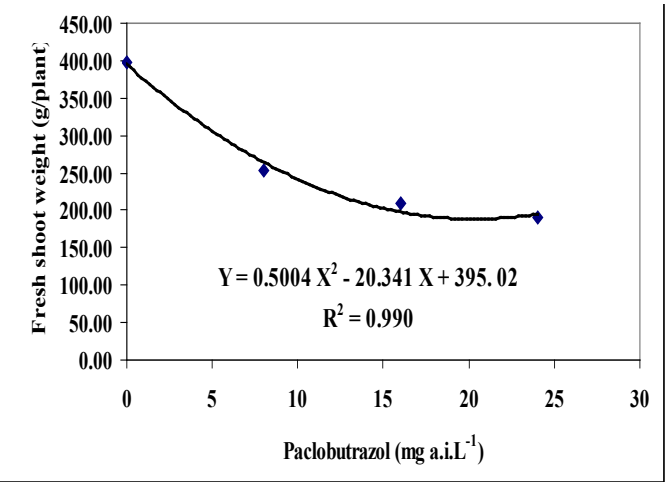

Fig. 8. Fresh shoot weight of Sanchezia nobilis plant as affected by foliar spray of paclobutrazol (mg a.i. $\left.\mathrm{L}^{-1}\right)$.

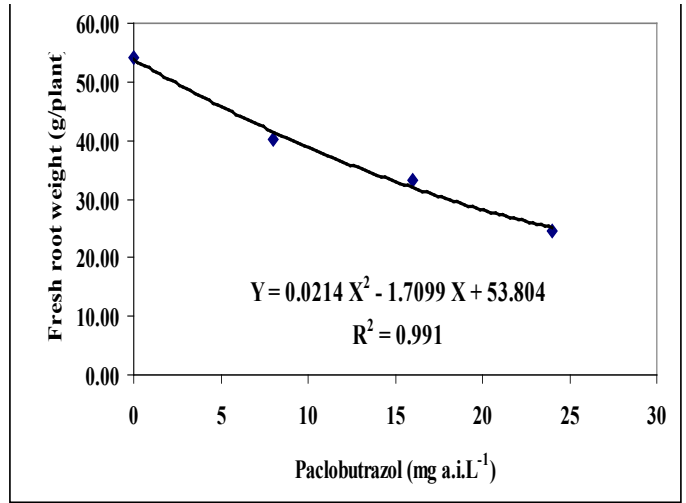

Fig. 9. Fresh root weight of Sanchezia nobilis plant as affected by foliar spray of paclobutrazol (mg a.i. $\left.\mathrm{L}^{-1}\right)$

TABLE 5. Effect of foliar application of micronutrients mixture and paclobutrazol (PB) on flowering Traits and leaves chlorophyll content of Sanchezia nobilis plant during 2015 and 2016 seasons.

\begin{tabular}{|c|c|c|c|c|c|c|c|c|c|}
\hline \multirow{3}{*}{$\begin{array}{l}\text { Micronutrients } \\
\text { mixture (ppm) }\end{array}$} & \multirow{3}{*}{$\begin{array}{c}\text { PB } \\
\left(\mathrm{mg} \mathrm{a.i.} \mathbf{L}^{-1}\right)\end{array}$} & \multicolumn{6}{|c|}{ Inflorescences per plant } & \multirow{3}{*}{\multicolumn{2}{|c|}{ SPAD Chlorophyll }} \\
\hline & & \multicolumn{2}{|c|}{ Number } & \multicolumn{2}{|c|}{ Fresh weight (g) } & \multicolumn{2}{|c|}{ Dry weight (g) } & & \\
\hline & & 2015 & 2016 & 2015 & 2016 & 2015 & 2016 & & \\
\hline \multirow{4}{*}{$\mathrm{C}_{0}$} & $\mathbf{0}$ & 1.33 & 1.00 & 20.79 & 15.00 & 4.17 & 3.00 & 47.50 & 42.93 \\
\hline & 8 & 1.67 & 1.67 & 25.47 & 24.80 & 4.95 & 4.82 & 54.40 & 52.30 \\
\hline & 16 & 1.33 & 1.00 & 18.62 & 13.60 & 3.69 & 2.67 & 59.10 & 58.60 \\
\hline & 24 & 0.00 & 0.00 & 0.00 & 0.00 & 0.00 & 0.00 & 48.70 & 44.17 \\
\hline \multicolumn{2}{|l|}{ Mean } & 1.08 & 0.92 & 16.22 & 13.35 & 3.20 & 2.62 & 52.43 & 49.50 \\
\hline \multirow{4}{*}{$\mathrm{C}_{1}$} & $\mathbf{0}$ & 2.00 & 1.67 & 33.60 & 27.47 & 6.96 & 5.68 & 51.00 & 49.73 \\
\hline & 8 & 2.33 & 2.00 & 38.45 & 32.40 & 7.59 & 6.37 & 63.53 & 60.67 \\
\hline & 16 & 2.00 & 2.00 & 30.00 & 29.40 & 5.75 & 5.75 & 65.47 & 63.77 \\
\hline & 24 & 0.00 & 0.00 & 0.00 & 0.00 & 0.00 & 0.00 & 53.73 & 49.00 \\
\hline \multicolumn{2}{|l|}{ Mean } & 1.58 & 1.42 & 25.51 & 22.32 & 5.08 & 4.45 & 58.43 & 55.79 \\
\hline \multirow{4}{*}{$\mathrm{C}_{2}$} & 0 & 2.67 & 2.40 & 48.06 & 40.78 & 10.41 & 8.80 & 55.53 & 52.27 \\
\hline & 8 & 3.00 & 3.00 & 52.35 & 51.00 & 10.83 & 10.49 & 65.33 & 62.90 \\
\hline & 16 & 2.00 & 2.00 & 32.50 & 29.60 & 6.50 & 5.92 & 64.53 & 63.93 \\
\hline & 24 & 0.00 & 0.00 & 0.00 & 0.00 & 0.00 & 0.00 & 59.80 & 54.23 \\
\hline \multicolumn{2}{|l|}{ Mean } & 1.92 & 1.85 & 33.23 & 30.34 & 6.94 & 6.30 & 61.30 & 58.33 \\
\hline \multirow{4}{*}{$\mathrm{C}_{3}$} & 0 & 2.00 & 2.00 & 38.00 & 36.60 & 8.11 & 7.85 & 57.07 & 55.67 \\
\hline & 8 & 3.00 & 2.67 & 54.45 & 46.06 & 11.33 & 9.51 & 64.97 & 63.80 \\
\hline & 16 & 2.40 & 2.20 & 41.12 & 39.38 & 8.06 & 7.79 & 65.33 & 64.20 \\
\hline & 24 & 0.00 & 0.00 & 0.00 & 0.00 & 0.00 & 0.00 & 60.63 & 55.73 \\
\hline \multicolumn{2}{|l|}{ Mean } & 1.85 & 1.72 & 33.39 & 30.51 & 6.88 & 6.29 & 62.00 & 59.85 \\
\hline \multirow{4}{*}{$\begin{array}{l}\text { Mean of } \\
\text { paclobutrazol }\end{array}$} & 0 & 2.00 & 1.77 & 35.11 & 29.96 & 7.41 & 6.33 & 52.78 & 50.15 \\
\hline & 8 & 2.50 & 2.34 & 42.68 & 38.56 & 8.68 & 7.80 & 62.06 & 59.92 \\
\hline & 16 & 1.93 & 1.80 & 30.56 & 27.99 & 6.00 & 5.53 & 63.61 & 62.63 \\
\hline & 24 & 0.00 & 0.00 & 0.00 & 0.00 & 0.00 & 0.00 & 55.72 & 50.78 \\
\hline \multicolumn{10}{|l|}{ LSD at $5 \%$} \\
\hline \multicolumn{2}{|c|}{ Micro-nutrients (M) } & 0.32 & 0.40 & 3.12 & 3.01 & 0.67 & 0.61 & 2.24 & 1.67 \\
\hline \multicolumn{2}{|c|}{ Paclobutrazol (PB) } & 0.40 & 0.48 & 2.45 & 3.06 & 0.51 & 0.65 & 1.54 & 1.56 \\
\hline \multicolumn{2}{|l|}{ M X PB } & 0.59 & 0.66 & 4.90 & 6.13 & 1.03 & 1.30 & 3.07 & 3.12 \\
\hline
\end{tabular}

$\mathrm{PB}=$ Paclobutrazol, a.i. $=$ active ingredient

$\mathrm{C}_{0}=$ control treatment (tap water), $\mathrm{C}_{1}=50 \mathrm{Zn}+50 \mathrm{Mn}+50 \mathrm{Fe}+50 \mathrm{~B}$ in ppm,

$\mathrm{C}_{2}=100 \mathrm{Zn}+100 \mathrm{Mn}+100 \mathrm{Fe}+100 \mathrm{~B}$ in ppm, $\mathrm{C}_{3}=150 \mathrm{Zn}+150 \mathrm{Mn}+150 \mathrm{Fe}+150 \mathrm{~B}$ in ppm

Egypt. J. Hort. Vol. 44, No. 2 (2017) 
of micronutrients mixtures increased total carbohydrates and leaves contents of $\mathrm{Zn}, \mathrm{Mn}, \mathrm{Fe}$ and $B$ in both seasons. The Maximum value of total carbohydrates (26.00 and $25.78 \%$ ) was determined in plants sprayed with micronutrients mixture at the level of $\mathrm{C}_{2}(100 \mathrm{Zn}+100 \mathrm{Mn}+100 \mathrm{Fe}+100 \mathrm{~B}$; in ppm), while the maximum values of $\mathrm{Zn}$ (29.38 and $28.20 \mathrm{ppm}$ ), Mn (21.85 and $20.08 \mathrm{ppm}), \mathrm{Fe}$ (341.93 and $327.63 \mathrm{ppm})$ and $\mathrm{B}$ (59.65 and $55.56 \mathrm{ppm})$ were determined in plants sprayed with micronutrients mixture at the level of $\mathrm{C}_{3}(150 \mathrm{Zn}+150 \mathrm{Mn}+$ $150 \mathrm{Fe}+150 \mathrm{~B}$; in ppm) in the first and second seasons, respectively. Total carbohydrates and micro elements in sanchezia leaves varied among plants treated with different concentrations of paclobutrazol. Foliar application of paclobutrazol at the level of $16 \mathrm{mg}$ a.i. $\mathrm{L}^{-1}$ markedly increased total carbohydrates (25.56 and $25.75 \%), \mathrm{Zn}(27.83$ and $29.05 \mathrm{ppm}), \mathrm{Mn}$ (23.00 and $21.53 \mathrm{ppm}), \mathrm{Fe}$ (315.50 and $321.55 \mathrm{ppm})$ and $\mathrm{B}$ (61.38 and 56.45 $\mathrm{ppm})$ in the first and second seasons, respectively. Increase leaves contents of total carbohydrates and micro elements by application of paclobutrazol to ornamental plants was reported by Mazher et al. (2014) and Matsoukis et al. (2015).

TABLE 6. Effect of foliar application of micronutrients mixture and paclobutrazol (PB) on chemical constituents of Sanchezia nobilis plant during 2015 and 2016 seasons.

\begin{tabular}{|c|c|c|c|c|c|c|c|c|c|c|c|}
\hline \multirow{2}{*}{$\begin{array}{l}\text { Micronutrients } \\
\text { mixture (ppm) }\end{array}$} & \multirow{2}{*}{$\begin{array}{c}\text { PB } \\
\left(\mathrm{mg} \mathrm{a.i.L} \mathbf{L}^{-1}\right)\end{array}$} & \multicolumn{2}{|c|}{$\begin{array}{c}\text { Total } \\
\text { carbohydrates } \\
\% \\
\end{array}$} & \multicolumn{2}{|c|}{ Zn (ppm) } & \multicolumn{2}{|c|}{ Mn (ppm) } & \multicolumn{2}{|c|}{$\mathrm{Fe}(\mathrm{ppm})$} & \multicolumn{2}{|c|}{ B (ppm) } \\
\hline & & 2015 & 2016 & 2015 & 2016 & 2015 & 2016 & 2015 & 2016 & 2015 & 2016 \\
\hline \multirow{4}{*}{$\mathrm{C}_{0}$} & 0 & 19.15 & 20.00 & 15.70 & 17.80 & 10.60 & 11.30 & 147.40 & 136.50 & 11.10 & 10.70 \\
\hline & 8 & 21.50 & 20.15 & 18.00 & 19.30 & 12.40 & 12.80 & 235.40 & 231.00 & 18.20 & 16.70 \\
\hline & 16 & 22.25 & 21.90 & 21.20 & 20.80 & 18.10 & 16.70 & 269.90 & 254.00 & 31.10 & 28.70 \\
\hline & 24 & 19.00 & 19.20 & 17.60 & 18.50 & 16.20 & 14.50 & 249.70 & 236.90 & 21.30 & 20.10 \\
\hline Mean & & 20.48 & 20.31 & 18.13 & 19.10 & 14.33 & 13.83 & 225.60 & 214.60 & 20.43 & 19.05 \\
\hline \multirow{4}{*}{$\mathrm{C}_{1}$} & 0 & 23.00 & 22.15 & 20.10 & 23.20 & 13.80 & 12.30 & 219.80 & 213.40 & 22.50 & 19.20 \\
\hline & 8 & 24.00 & 24.60 & 24.30 & 25.40 & 16.20 & 14.70 & 255.10 & 246.00 & 28.70 & 25.30 \\
\hline & 16 & 25.20 & 26.00 & 26.30 & 29.80 & 22.50 & 21.10 & 278.10 & 265.20 & 56.30 & 52.70 \\
\hline & 24 & 22.60 & 21.10 & 21.60 & 22.40 & 17.40 & 15.80 & 260.20 & 254.40 & 35.10 & 29.60 \\
\hline Mean & & 23.70 & 23.46 & 23.08 & 25.20 & 17.48 & 15.98 & 253.30 & 244.75 & 35.65 & 31.70 \\
\hline \multirow{4}{*}{$\mathrm{C}_{2}$} & 0 & 24.70 & 23.60 & 25.10 & 23.80 & 16.80 & 16.00 & 256.00 & 240.10 & 33.30 & 31.40 \\
\hline & 8 & 25.50 & 26.70 & 26.50 & 25.90 & 19.30 & 17.60 & 324.00 & 334.90 & 46.40 & 39.20 \\
\hline & 16 & 29.20 & 28.80 & 31.00 & 32.60 & 24.50 & 23.80 & 333.80 & 392.00 & 76.00 & 68.20 \\
\hline & 24 & 24.60 & 24.00 & 19.40 & 20.40 & 19.10 & 17.60 & 273.50 & 270.50 & 48.70 & 41.30 \\
\hline Mean & & 26.00 & 25.78 & 25.50 & 25.68 & 19.93 & 18.75 & 296.83 & 309.38 & 51.10 & 45.03 \\
\hline \multirow{4}{*}{$\mathrm{C}_{3}$} & 0 & 23.20 & 22.40 & 26.80 & 25.40 & 18.90 & 17.60 & 283.00 & 262.30 & 43.80 & 41.80 \\
\hline & 8 & 24.30 & 24.00 & 30.40 & 28.20 & 20.70 & 19.60 & 341.70 & 358.10 & 52.40 & 48.10 \\
\hline & 16 & 25.60 & 26.30 & 32.80 & 33.00 & 26.90 & 24.50 & 380.20 & 375.00 & 82.10 & 76.20 \\
\hline & 24 & 22.30 & 22.00 & 27.50 & 26.20 & 20.90 & 18.60 & 362.80 & 315.10 & 60.30 & 56.15 \\
\hline Mean & & 23.85 & 23.68 & 29.38 & 28.20 & 21.85 & 20.08 & 341.93 & 327.63 & 59.65 & 55.56 \\
\hline \multirow{4}{*}{$\begin{array}{l}\text { Mean of } \\
\text { paclobutrazol }\end{array}$} & 0 & 22.51 & 22.04 & 21.93 & 22.55 & 15.03 & 14.30 & 226.55 & 213.08 & 27.68 & 25.78 \\
\hline & 8 & 23.83 & 23.86 & 24.80 & 24.70 & 17.15 & 16.18 & 289.05 & 292.50 & 36.43 & 32.33 \\
\hline & 16 & 25.56 & 25.75 & 27.83 & 29.05 & 23.00 & 21.53 & 315.50 & 321.55 & 61.38 & 56.45 \\
\hline & 24 & 22.13 & 21.58 & 21.53 & 21.88 & 18.40 & 16.63 & 286.55 & 269.23 & 41.35 & 36.79 \\
\hline
\end{tabular}

$\mathrm{PB}=$ Paclobutrazol, a.i. $=$ active ingredient

$\mathrm{C}_{0}=$ control treatment (tap water), $\mathrm{C}_{1}=50 \mathrm{Zn}+50 \mathrm{Mn}+50 \mathrm{Fe}+50 \mathrm{~B}$ in ppm,

$\mathrm{C}_{2}=100 \mathrm{Zn}+100 \mathrm{Mn}+100 \mathrm{Fe}+100 \mathrm{~B}$ in ppm, $\mathrm{C}_{3}=150 \mathrm{Zn}+150 \mathrm{Mn}+150 \mathrm{Fe}+150 \mathrm{~B}$ in ppm 


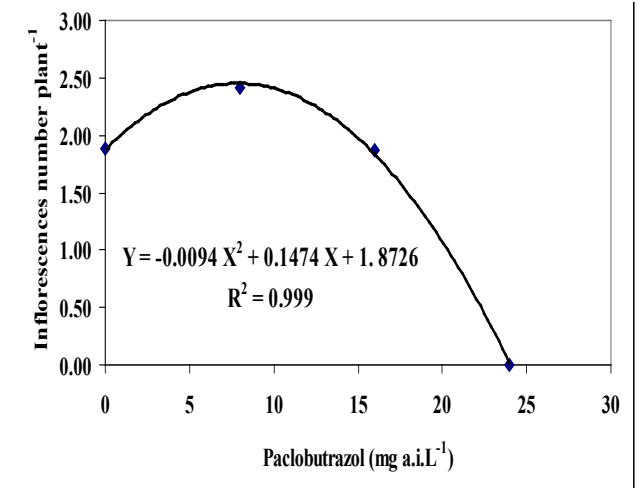

Fig.10. Inflorescences number of Sanchezia nobilis plant as affected by foliar spray of paclobutrazol (mg a.i. $\left.\mathrm{L}^{-1}\right)$.

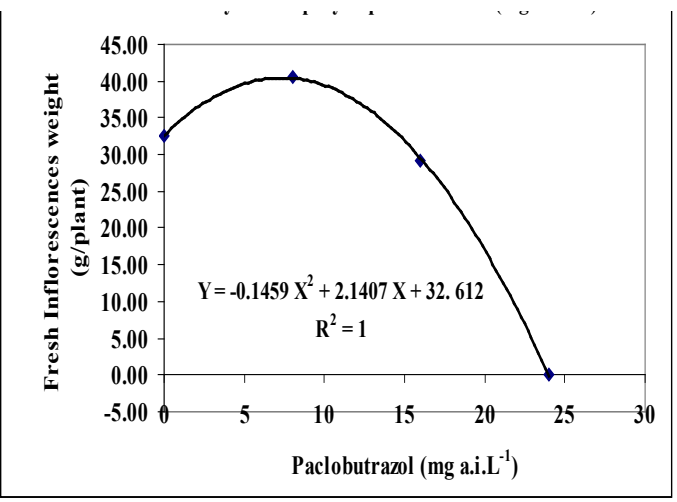

Fig.11. Fresh Inflorescences weight of s Sanchezia nobilis plant as affected by foliar spray of paclobutrazol (mg a.i. $\left.\mathrm{L}^{-1}\right)$.

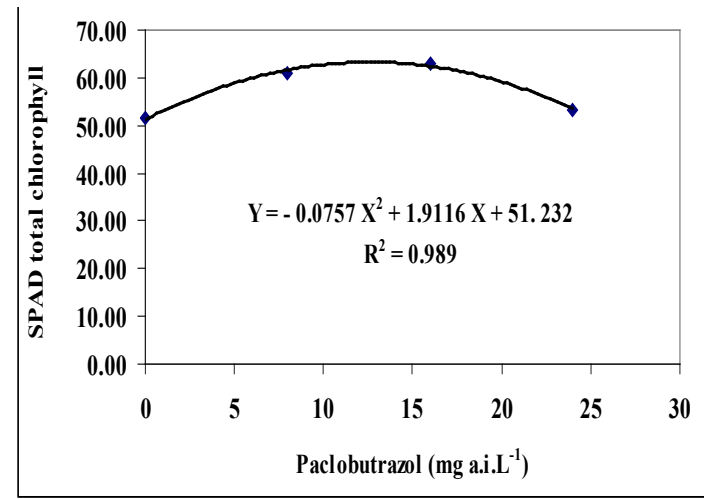

Fig.12. SPAD total chlorophyll of Sanchezia nobilis plant as affected by foliar spray of paclobutrazol (mg a.i. $\left.\mathrm{L}^{-1}\right)$.

\section{Conclusions}

Paclobutrazol was effective in controlling growth of sanchezia ornamental plant. Applications of micronutrients and paclobutrazol as spraying at different concentrations were sufficient to provide plant growth control and increase the diversity of potted plants grown for the ornamental plants market. Growth and flowering response of sanchezia plant should be considered, whereas the highest concentration of paclobutrazol (24 mg a.i. $\left.\mathrm{L}^{-1}\right)$ under the conditions of this study prevented flowering.

\section{Acknowledgements}

This work was supported by the Faculty of Agriculture, Cairo University.

Funding statements

Faculty of Agriculture, Cairo University, Egypt

Conflicts of interest

I has no conflicts of interest to declare

\section{References}

Abd El- Aziz, N.G. andBalbaa, L. K. (2007) Influence of tyrosine and zinc on growth, flowering and chemical constituents of Salvia farinaceaplants. $J$. Appl. Sci. Res., 3 (11), 1479-1489.

Agehara, S. andLeskovar, D.I. (2014) Age dependent effectiveness of exogenous abscisic acid in height control of bell pepper and jalapeno transplants. Sci. Hort.,175,193-200.

Aziz, E.E., Ezz El-Din, A.A. and Omer, E.A. (2010) Influence of zinc and iron on plant growth and chemical constituents of Cymbopogoncitratus grown in newly reclaimed land.International $J$. Academic Res., 2 (4), 278- 283.

Bashir, M.A., Ahmad, W., Ahmad, K.S., Shafi, J., Shehzad, M.A., Sarwar, M.A.,Ghani, I. and Iqbal, M. (2013) Efficacy of foliar application of micro nutrients on growth and flowering of Gerbera jamesonii L. Universal Journal of Agricultural Research, 1(4), 145-149.

Bai, S., Chaney, W. and Qi, Y. (2004) Response of cambial and shoot growth in trees treated with paclobutrazol. Journal of Arboriculture, 30 (3), 137-145.

Basra, A.S. (2000) Plant growth regulators in agriculture and horticulture: Their role and commercial uses. Haworth Press, Binghamton, NY. 
Bekheta, M. A., El-Ghourab, A.H. and Mahgoub, M.H. (2003) Influence of stigmasterol and uniconazole on growth, endogenous hormones, chemical composition and radical scaving activity of thyme (Thymus syrpyllum L.). Egypt, J. Res. NRC, 1, $523-545$.

Carver, S.T., Arnold, M.A., Byrne,D.H., Armitage, A.R., Lineberger, R.D. and King, A.R. (2014) Growth and flowering responses of sea marigold to daminozide, paclobutrazol, or uniconazole applied as drenches or sprays. Journal of Plant Growth Regulation, 33 (3), 626-631.

Davis, T.D., and Curry, E.A. (1991) Chemical regulation of vegetative growth. Critical Rev. Plant Sci., 10 (2), 151-188.

Davis, T.D., Steffans, G.L. and Sankhla, N. (1988) Triazole plant growth regulators. Hort. Rev., 10, 63-105.

Dubois, M., Gilles, K.A., Hamilton, J.K., Repers, P.A. and Smith, F. (1956) Colorimetric method for determination of sugars and related substances. $J$. Analytical Chemistry, 28 (3), 350-356.

El- Quesni, E.M.F., Farahat, M.M., El-Khateeb, M.A., El-Leithy, A.S. andHashish, K.H.I. (2014) Effect of some micro-elements of iron, manganese and zinc on vegetative growth and chemical composition of Paulownia kawakamiiseedlings. Middle East Journal of Agriculture Research, 3 (4), 820-826.

Farahat, M.M., Soad, M.M.,Lobna, S.T. and Fatma, E.M. (2007) Response of vegetative growth and some chemical constituents of Cupressussempervirens L. to foliar application of ascorbic acid and zinc at Nubaria. World .J. Agric. Sci., 3 (4), 496-502.

Fatma, E. M. Q., Magda, M.K. and Mona, H.M. (2007) Some studies on the effect of putrescine and paclobutrazol on the growth and chemical composition of Bougainvillea glabraL. at Nubaria. American-Eurasian J. Agric. Environ. Sci., 2 (5), 552-558.

Fletcher, R.A., Gilley, A., Sankhla, N. and Davis, T.D. (2000) Triazoles as plant growth regulators and stress protectants. Hort. Rev. 24, 55-138.

Freed, R.S.P., Einensmith, S., Gutez, S., Reicosky, D., Smail, V.W. and Wolberg, P. (1989) MSTAT-C analysis of agronomic research experiments. Michigan Univ. East Lansing, USA.

Gomez, K.A. and Gomez, A.A. (1984) Statistical Procedures for Agricultural Research, $2^{\text {nd }}$ ed., John Wily\& Sons.Inc. New York, USA., pp. 97-107.
Grossi, J.A.S., Tinoco, P.J.M.A., Barbosa, J.G., Finger, F.L.and Cecon, P.R. (2005) Effects of paclobutrazol on growth and fruiting characteristics of 'pitanga' ornamental pepper. Proc. $V^{\text {th }}$ IS on New Flor. Crops, A.F.C. Tombolato and G.M. DiasTagliacozzo, (Ed.), pp. 333- 336.

Issac, R.A. and Kerber, J.D. (1971) Atomic absorption and flamephotometry: techniques and Uses in soil, plant and water analysis. In instrumental methods for analysis of soil and plant tissue. Soil Sci. Soc. Amer., Madison, WI, USA, pp. 17-37.

Khalil, I.A. (1995) Chlorophyll and carotenoids contents in cereals as affected by growth retardants of triazole series. Cereal Res. Commun.,23,183-189.

Mansuroglu, S., Karaguzel, O., Ortacesme, V. and Sayan, M.S. (2009) Effect of paclobutrazol on flowering, leaf and flower colour of Consolidaorientalis. Pak. J. Bot., 41 (5), 2323-2332.

Matsoukis, A., Gasparatos, D. and SERELI, A.C. (2015) Micronutrient content in relation to specific leaf area, light regime and drenched-applied paclobutrazol in Lantana Camara L. Current Agriculture Research Journal, 3 (2), 101-104.

Mazher, A.A.M., Abdel-Aziz, N.G., El-Maadawy, E.I., Nasr, A.A. and El-Sayed, S.M. (2014) Effect of gibberellic acid and paclobutrazol on growth and chemical composition of Scheffleraarboricola plants. Middle East Journal of Agriculture Research, 3 (4), 782-792.

Meijon, M., Rodriguez, R., Canal, M.J. and Feito, I. (2009) Improvement of compactness and floral quality in azalea by means of application of plant growth regulators. Sci. Hort.,119,169-176.

Mutlu, S.S. and Agan, E. (2015) Effects of paclobutrazol and pinching on ornamental pepper. Hort. Technology, 25 (5), 657-664.

Netto, A.T., Campostrini, E.J., Oliveira, G. and Bressan, S.R. E. (2005) Photosynthetic pigments, nitrogen, chlorophyll a fluorescence and SPAD 502 reading in coffee leaves. Scientia Hort., 104 (2), 199-209.

Papageorgiou, Giaglaras and Maloupa, E. (2002) Effects of paclobutrazol and chlormequat on growth and flowering of lavender. Hortechnology, 12(2), 236-238.

Pinto, A.C.R., Rodrigues, T.J.D., Leite, I.C. and Barbosa, J.C. (2005) Growth retardants on development and ornamental quality of pttedlilliput' Zinnia elegans JACQ. Sci. Agric. (Piracicaba, Braz.), 62 (4), 337-345.

Egypt. J. Hort. Vol. 44, No. 2 (2017) 
Piper, O. S. (1947) Soil and Plant Analysis.Adelaide Univ., Adelaide, Australia, pp.258-275.

Putra ETS, Zakaris W, Abdullah, N.A.P. and Saleh, G.B. (2012) Stomatal morphology, conductance and transpiration of Musa sp. cv. Rastali in relation to magnesium, boron and silcon availability. Amer. J. Plant Phys., 7, 84-96.

Rademacher, W. (2000) Growth retardants: Effects on gibberellin biosynthesis and other metabolic pathways. Ann. Rev. Plant Physiol. Plant Mol. Biol., 51, 501-531.

Tukey, H.B., Went, F.W., Muir, R.M. and Van Overbeek, J. (1953) Nomenclature of chemical plantgrowth regulators: Report by a committee of the American Society of Plant Physiologists. Plant Physiol., 29, 307-308.
Vasconcelos, M.W., Clemente, T. andGrusak, M. (2014) Evaluation of constitutive iron reductase (AtFRO2) expression on mineral accumulation and distribution in soybean (Glycine max. L). Front Plant Sci., 5, 1-12.

Watson, L., and Dallwitz, M. J. (1994). The Families of Flowering Plants: Descriptions, Illustrations, Identification, and Information Retrieval, CSIRO Publications: Melbourne, 14 (5), p.486.

Yadegari, M. (2017) Effects of $\mathrm{Zn}, \mathrm{Fe}, \mathrm{Mn}$ and $\mathrm{Cu}$ foliar application on essential oils and morphophysiological traits of lemon balm (Melissa officinalis L.). Journal of Essential Oil Bearing Plants, 20 (2), 485-495.

(Received 22/9/2017;

accepted 12/12/2017)

\section{التحكم في نمو نبات السانكيزيا من خلال الرش الورقي للعناصر الصغرى والباكلوبيترازول}

آمال عبد الخالق محمد هيكل

قسم بساتين الزينة ـ كلية الزر اعة - جامعة القاهرة ـ القاهرة ـ مصر.

نفذت تجربة أصص لتقييم فاعلية الرش الورقي بمخلوط العناصر الصغرى ( زنلك - منجنيز - حديد - بورون)

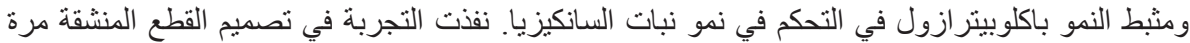

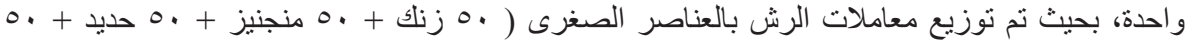

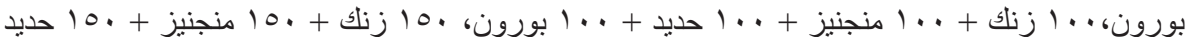

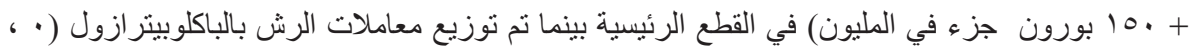

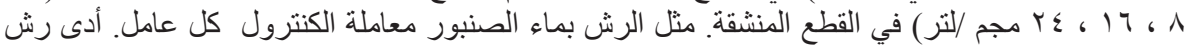

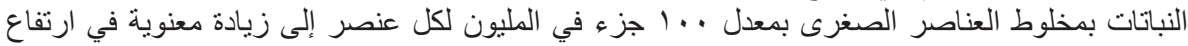

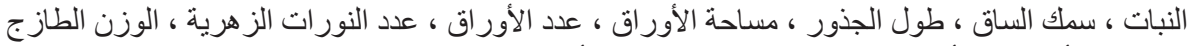

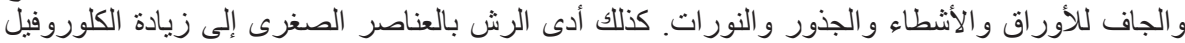

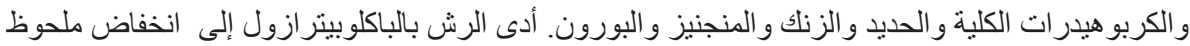

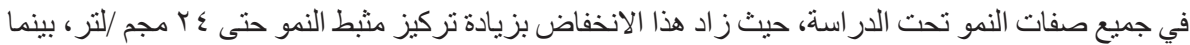

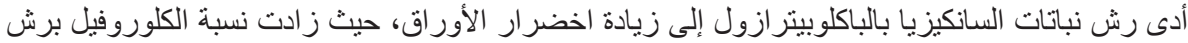

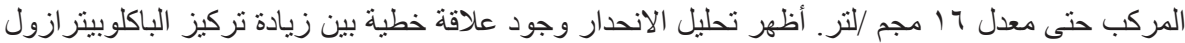

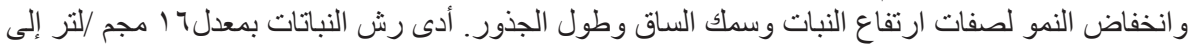

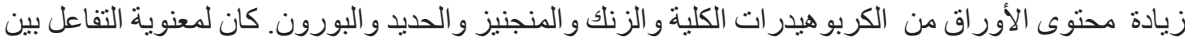

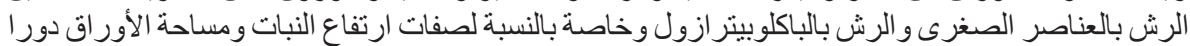

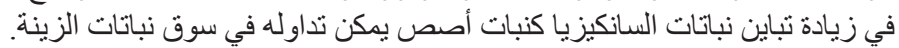

